\title{
The Use Of Natural Sciences Kits In Distance Learning For Higher Education Of Bachelor Of Elementary School Teacher Education Program
}

\author{
A. A. Ketut Budiastra \\ Universitas Terbuka, Indonesia. \\ Udan Kusmawan \\ Universitas Terbuka, Indonesia. \\ Iwan Wicaksono \\ Universitas Jember, Indonesia.
}

\author{
Kartimi \\ IAIN Syekh Nurjati Cirebon, Indonesia.
}

\begin{abstract}
The teaching and learning process of natural science cannot be separated from practicum activities. Likewise, the practicum activities of natural science in bachelor of Elementary School Teacher Education Program have their own characteristics. This study aims at examining the use of Natural Science Kits in the implementation of the practicum of natural sciences with the provisions contained in the practicum of natural sciences college subject of bachelor of Elementary School Teacher Education Program, Faculty of Teacher Training and Education, Universitas Terbuka. This study is categorized as a qualitative descriptive research. This study involved 177 undergraduate students of bachelor of Elementary School Teacher Education Program, UT, which is spread across five (5) regional offices of UT, and it conducted from March to December 2018. The results of this study showed that it can be concluded that the practicum of natural science in elementary schools can be carried out using the Natural Science Kits belonging to bachelor of Elementary School Teacher Education Program, UT, although the Natural Science Kits and its management activities still needs to be improved and refined.
\end{abstract}

Keywords: practicum, Natural Science KITS, Elementary School Teachers, distance learning

\section{INTRODUCTION}

One of the characteristics of Distance Education (DE) for Higher Education is that there is a distance between educators and students. This distance has enormous implications for the teaching-learning process, in which most of the process takes place remotely. The face-to-face session is very minimal. Especially, with the advanced information technology, face-to-face seems to be the last alternative. Under these circumstances, the facilitation provided by the educators of DE plays a very important role. The quality and quantity of facilities must be able to make students have a good interaction with various learning resources.

In the distance learning system as implemented at Universitas Terbuka (UT) Indonesia, the perseverance in attending lectures can be transferred into the perseverance in utilizing the learning resources available at UT and the tenacity in fulfilling and doing given individual tasks. For this reason, the students of UT must organize and use a learning environment truly 
supporting their learning activities. With the support of an adequate learning environment, interest, passion, joy, and continuity in learning will be guaranteed, and it won't waste much time so that the learning activities will be effective. In accordance with the form of distance learning system, the students of UT conduct learning activities by dealing directly with the media, in this case, the main media for learning is printed media in the form of modules. Besides using printed media as modules, there are also other media used like audio media from cassette. In addition, there are also other supporting books.

Teaching materials often used for individual learning include various printed and non-printed materials, such as course books, student learning guides, structured notes, organized text material, audio programs, video programs, audio-video programs, computer programs, and others. There are several factors can affect the quality of teaching materials, and they must always be considered in the process of developing teaching materials. Those factors are content, scope, legibility, language, illustrations, appearance, and packaging. The quality of teaching materials developed depends on the accuracy of calculating these factors (Belawati, 2003). The depth and extent of the teaching materials contents are interrelated to one another, and both greatly determine the level of teaching material developed. The main reference in determining the depth and extent of the teaching materials content is the curriculum, specifically the general and specific learning objectives and the essential topics of a subject listed in the curriculum.

Because of the distance between the students and the educator, whether or not the interaction occurs depends more on the students themselves. Students really have full autonomy over their learning process. They are the one determining whether the learning process has occurred or not. They are the one knowing whether the ability that should be mastered is really mastered deeply or just to meet the requirements for graduation. They are the one knowing when they have to study, when they have to discuss with his friends, when they have to conduct laboratory activities, and so on. It is what is called an independent learner or referred to as an "independent learner" which is an essential aspect of learning at DE. Independent learning or free to study is a learning activity where the learning objectives and how to achieve that goal are determined by students (Mudjiman, 2008).

However, it doesn't mean that the educators and managers of DE do not do nothing. They must provide learning services in the form of various conditions allowing students to use their independence to learn. A set of teaching materials and guidelines providing direction for students in the learning process must be provided. The service is a learning aid, basically consisting of academic and non-academic learning assistance. Thus, there are three main aspects of learning in the DE which are the distance between educators and students, the independence, and the learning services.

In the program of DE, practicums are often a serious obstacle. Although only a small part of the entire study time, the students of DE will experience problems when they have to do practical work outside their work/teaching place. For the students of bachelor of Elementary School Teacher Education Program, Faculty of Education and Teacher Training, UT or (students of bachelor of ESTE Program - UT), some types of Natural Science practicum activities can use the Natural Science kits sent to the students. However, this method is not always easy to be implemented. For example, for more complex practicum done by bachelor students of Departements of Mathematic and Science, UT, it must be carried out in the laboratories at state universities or private universities which have more complete laboratories and the laboratories are located closer to students. It is in line with the results of the study conducted 
by Gecer \& Ozel (2012) stating that some of the obstacles in the implementation of natural science practicum in schools include insufficient labs and equipment, and so on.

Practicum is one form of learning activities through observation, experiment, or testing a concept, and the principles carried out inside and outside the laboratory with the aim of strengthening the material of one or several college subjects. In addition, practicum can also: (1) fostering or increasing the students' observation, (2) stimulating the students' curiosity, (3) improving the accuracy, objectivity, and honesty of students. Practicum college subjects at the UT are stand-alone courses. The material from practicum college subjects at UT is a guide to activities in carrying out the practicum which is packaged in the form of practicum modules. At UT, practicum is conducted by students with the guidance of instructors appointed by the Regional Office (RO) that is local distance learning service unit of UT which is spread throughout Indonesia. The evaluation of practicum implementation at UT has not been carried out comprehensively. Budiastra, et al. (2001) in their research results, they stated that most students did not carry out the practicum as they should. Moreover, it was also revealed one of the things causing students not to do practicum because there was no comprehensive management system for practicum implementation.

Professional teachers should have a deep understanding of the field of study and an awareness of the difficulty of the material to be taught to students. If the teachers are not prepared to teach the field of study, there is a tendency for teachers to teach as taught to them. If they are taught with lecturing method, they will teach using the lecturing method as well even though the method is not quite right (Teachers tend to teach as they were taught. If they were taught through lecture, they likely to lecture, even if such instruction is inappropriate for their students), (McDermott, Shaffer, \& Constantinou, 2000). In this case, to provide skilled teachers in teaching natural science lessons integrating among practicum activities of natural science in the lessons in elementary schools, they must be prepared since they study/go to college by giving examples and exercises on how to integrate natural science lessons with practical activities or science experiments in elementary school.

From the results of monitoring of the college subject activities of practicum in the bachelor of Elementary School Teacher Education Program, UT, information was obtained that the Natural Science Kits sent to each study group was not maximally used for the Natural Sciences practicum. Some of the Natural Science Kits received by Student Study Groups were not in an incomplete state, for example, a report from the coordinator of academic services from RO of UT Mataram (registration period of 2017.2).

In addition, from reports on the results of monitoring the implementation of the face to face tutorial of the Natural Science practice activities of the basic education program in Student Study Groups in West Jakarta during the registration period of 2017/ 2018.1, information was obtained that the Natural Science Kits sent to each Student Study Group was usually only used once and after that the Natural Science Kit was stacked in the used tutorial a room. There is a tendency for the condition of the Natural Science Kits to be poorly maintained. To assess the utilization of the Natural Science Kits and the implementation of Natural Sciences Practicum activities in each Student Study Group, it is necessary to conduct an evaluation program regarding the use of Natural Science Kits in the college subject of Natural Sciences Practicum at the bachelor of Elementary School Teacher Education Program.

Based on the background of the problem above, the main problem in this study or as a grand tour question is how the use of Natural Science Kits in the college subject of Natural Sciences Practicum at the bachelor of ESTE Program - UT, is. Specifically, this study aims at finding out 
the following matters: (1) Factors supporting the use of Natural Science Kits in the college subject of Natural Sciences Practicum at the bachelor of ESTE Program - UT; (2) Factors constraining the use of Natural Science Kits in the college subject of Natural Sciences Practicum at the bachelor of ESTE Program - UT; (3) The efforts having been made by students and educators to facilitate the use of Natural Science Kits in the course of Natural Sciences Practicum at the bachelor of ESTE Program - UT.

\section{Program Objectives}

\section{LITERATURE REVIEW}

In accordance with Law No. 20 of 2003 concerning the National Education System, PP No. 19 of 2005 concerning National Education Standards, and Law No. 14 of 2005 concerning Teachers and Lecturers, as well as the division of authority in the implementation of government and education decentralization, the objectives of the implementation of the Elementary School Teacher Education Program are set by the Central Government, the Directorate General of Higher Education. According to the Directorate General of Higher Education, the objective of organizing in-service training of bachelor of Elementary School Teacher Education Program is to prepare prospective elementary school teachers meeting national standards, so that the right qualifications, quality, number, and distribution can be achieved. Meanwhile, the implementation of in-service training of bachelor of Elementary School Teacher Education Program aims at providing access to elementary school teachers to improve their ability to meet national standards so that the right qualifications and quality can be achieved.

Practicum activities carried out independently by students are difficult to control either by the RO or by the Central UT. Therefore, this study aims at developing a model for conducting Natural Science practicum at UT, so that the practicum implementation at UT has good quality, and the objectives of practicum can be realized. Based on the data that has been collected, while the authors conclude that the implementation of practicum by UT students is not as easy as conventional university. Students are difficult to meet one another, because the location of their residence is spread out at RO's region, so the RO has difficulty in determining the implementation of practical work.

\section{Graduates Competences}

Basically, the competency profile of graduates of bachelor of Elementary School Teacher Education Program in distance learning are the same with who are graduates of bachelor of Elementary School Teacher Education Program in Conventional Learning. The development of the competency profile of both graduates was developed by referring to the Teacher Competency Standards for Elementary Schools and Islamic Elementary Schools for the Graduates of Bachelor of Elementary School Teacher Education Program established by the Directorate General of Higher Education in 2006. Teacher competencies of Elementary Schools and Islamic Elementary Schools Teacher are grouped into four core competencies. The four competencies include: (1) in-depth introduction of students, (2) mastery of the field of study, (3) organizing learning that educates, and (4) continuous development of professional abilities. These four competencies are the scientific basis of the art of teaching in which if it is applied in authentic conditions at school, it will enable the mastery of the professional competence of an Elementary Schools and Islamic Elementary Schools Teacher.

In terms of competency level, Minister of National Education Decree No. 045 / U / 2002 concerning the Graduates Competency Level of Study Program in Higher Education states that the competency of college graduates consists of three levels of ability the three levels include the main competencies, supporting competencies, and other competencies. Main Competence 
consists of sets of absolute abilities that are necessary in performing teacher training, enabling teachers to make professional decisions in the implementation of their tasks. The ability to make this decision is a distinctive essence, and it must be owned by elementary school/Islamic elementary school teachers. Supporting Competence is a set of capabilities serving to improve the stability of the implementation of expert services in accordance with the type and authority. Mastery of these abilities establishes mastery of key abilities. Other competencies are additional capabilities that can complement the competency in implementing basic tasks as a classroom teacher.

\section{Natural Sciences Practicum at the bachelor of ESTE Program - UT}

Practicum is a part of teaching that aims at testing and implementing what is obtained in theory in real. In a more specific understanding, practicum is one form of teaching and learning activities that aims at strengthening student knowledge of course material through application, analysis, synthesis, and evaluation of theories carried out both in the laboratory or in the field (KBBI, 2016).

The presentation of the college subject of Natural Science Practicum offered at the bachelor of ESTE Program - UT, is somewhat different from the practical courses offered by face-to-face tertiary institutions. For example, there is a standalone Practicum course, but the material provided is still integrated in the courses offered. In the bachelor of Elementary School Teacher Education Program, UT, several courses requiring practicum activities are put together in one course, the college subject of Natural Science Practicum.

Meanwhile, Zainuddin (2001) in detail, stated that practicum: (1) can be used to practice the skills needed by students; (2) gives students the opportunity to apply and integrate their real knowledge and skills into practice; (3) prove something scientifically or conduct scientific inquiry; and (4) appreciate the knowledge and skills possessed. In this case, it is clearly seen that the inquiry cannot be separated from practicum activities.

In the field of science, there are at least four reasons put forward by science education experts regarding the importance of practicum activities, which are: (1) practicum evokes motivation to study science; (2) practicum develops basic skills in conducting experiments; (3) practicum becomes a vehicle for learning a scientific approach; and (4) practicum supports understanding subject matter (Woolnough \& Allsop, 1994). Practicum aims at helping students understand concepts and principles better. The things that are improved in practicum according to Prasetyo (2001) are as follows: (1) attitude towards physics; (2) scientific attitude; (3) scientific discoveries; (4) concept development; and (5) technical skills. In its implementation, practicum often takes a lot of time or in other words the time provided is too short, and students do not finish their practicum. Tools and materials have always been a problem for some schools with limited laboratory resources to carry out learning through practicum. Therefore, it must be remembered that besides practicum can provide benefits in realizing effective physics learning, it turns out that in practice, practicum is a special form of learning, which requires great effort and cost (Darmayanti et al., 2007)

Practicum is a controlled task dealing with the validation of facts or the relationship between facts (Curriculum as result of Decree of the Minister of National Education No. 107/U/2001). Natural Science practicum is an activity to verify the facts or truth of science concepts through thinking skills and scientific work. Practicum involves students or college students in how to find and learn through direct experiences. These kinds of activities are an integral part of teaching good physics (Prasetyo, 2001). Practicum involves students in scientific discoveries putting them in the position of asking questions, making observations, organizing data, and 
others. The activity allows students to plan and involve themselves in investigation or taking part in activities that can help them improve laboratory engineering skills.

\section{Laboratory and Scientific Process}

Laboratory is a place to explore natural phenomenon which is equipped with complicated and complex equipment. This assumption is actually not wrong because the laboratory is a place used to conduct experiments. Whereas, laboratory means: (1) a building, part of building, or other place equipped to conduct scientific experiments, tests, investigating, etc., or to manufacture chemicals, medicines, or the like; (2) any place, situation, set of conditions, or the like, conductive to experimentation, investigation, observation, etc., anything suggestive of scientific laboratory; (3) serving a function in a laboratory; (4) relating to techniques of work in a laboratory: laboratory methods; laboratory research, (Random House Webster's, 2000). Laboratory is: (1) a building or part of a building that is equipped with equipment to carry out an experiment, test, investigation, etc. ... or a place to produce chemicals, drugs, or as like; (2) places, situations, certain conditions, to conduct observations, experiments, investigations, and matters related to scientific activities; (3) assisting several functions of laboratory activities; (4) with regard to techniques or ways of working in a laboratory: methods of working in a laboratory, research in a laboratory). In other words, the laboratory is a place where experiments and research are carried out. This place can be a closed room such as rooms or open spaces or school gardens and so on. In a limited understanding, a laboratory is a closed room where experiments and research are carried out. Laboratory is a place or building containing tools and materials used for science learning (Biology, Physics, Chemistry), while the laboratory function helps students to establish knowledge about natural phenomena and the development of skills, abilities through scientific activities to obtain generalizations or conclusions in the form of scientific explanations. The facilities and infrastructure of the Natural Sciences laboratory include, among others, the layout of the space for experiments, the tools and experimental materials needed to support learning (Indrawan, 2015).

Generally speaking, the functions of the laboratory are: (1) as a place to practice and understand concepts having been learned previously in the classroom or at the lecture site; (2) as a place to solidify the knowledge already possessed and to discover new concepts and principles; (3) as a place to develop teaching methods in the field of science; and (4) as a place to conduct research both in the scientific field and in the teaching methods.

There are several goals that can be achieved by using the laboratory as an arena for learning, including: (1) Studying in the laboratory with the aim to match what is theoretically obtained from activities in the classroom with the reality of the trials results in experiments; (2) Duplicative laboratory activities; (3) This activity mimics what other people (experts) have done to obtain the same data; (4) Verificative activities. In this case, the laboratory activities are used to verify or prove whether the data obtained by the experts have indeed been tested and will give the same results when done by other people; (5) Explorative activities. This activity aims at obtaining new phenomena by using plans that are arranged systematically. The steps compiled are phased in starting from: (a) identifying of the problem; (b) formulating the problem; (c) constructing a new hypothesis or proposition; (d) conducting experiments with the aim of obtaining data to test the truth of new hypotheses or propositions; and (e) drawing conclusions.

Process skills of basic science are the skills that have to be owned by elementary students regarding science. In this learning method, children/students are required to conduct their own trials toward science material/natural phenomena that arise in the student's daily environment. Therefore, it is expected that by trying the practicum itself, students can find the 
answers to their problems, and the goals of education and science learning outcomes will later run optimally. Here, the teacher must always supervise and be a good facilitator for sure. The way to do process skills of basic science is that the teacher is obliged to guide his/her students to do the testing process, both done in the laboratory and in the classroom. The teacher gives in-advance briefing by conveying the learning objectives, practicum procedures, and which will be obtained by students. In the learning process, the teacher does not have to be the main source of answers to students' problems. Let students find their own answers to scientific problems.

\section{Research Design}

\section{METHODOLOGY}

This study is categorized as a qualitative descriptive research.

\section{Population and Sample}

In this study, the population are elementary school teachers who are also students of bachelor of Elementary School Teacher Education Program in RO of UT Pangkalpinang, Serang, Jakarta, Bandung, and Denpasar. The reason for choosing the fifth (5) RO's as sample is because the five RO's represent the RO's in the Western and Central Indonesia regions. Samples were taken using purposive sampling techniques, which are: (1) as many as 177 respondents were asked to fill out questionnaires distributed to five RO's. As many as 50 people are for focus group discussions (FGD) in which 10 people each are for the FGD in each five RO's. A total of 5 tutors to be observed at the tutorial session ( 1 tutor for each R0). There are 5 leaders of RO's of UT (1 person for each RO/Coordinator for Academic Services). Management of Student Study Group consists of 5 people (1 person for each RO of UT).

\section{Research Site and Time}

This study was conducted in five (5) R0 which are Pangkalpinang, Serang, Jakarta, Bandung, and Denpasar, specifically, students of bachelor of Elementary School Teacher Education Program. This study was conducted from March to December 2018.

\section{Data Collection Technique}

Data was collected by distributing questionnaires as the main data collection instruments. Besides the questionnaires as an instrument, an interview guideline used to obtain data from students, tutors, managers at RO, and managers of student study groups was also developed.

Interviews were conducted by means of probing, but it still based on the references in the interview instrument that had been prepared. For in-depth interviews with students of bachelor of Elementary School Teacher Education Program, UT, focus group discussion (FGD) was conducted. In addition, observations on the implementation process of the Natural Science practicum were also carried out during the tutorial activities.

\section{Data analysis Technique}

The analysis technique for each research result data is carried out as follows. (1) Factors supporting the use of the Natural Sciences kits in the college subject of Natural Sciences Practicum; (2) Factors detaining the use of the Natural Sciences kits in the college subject of Natural Sciences Practicum; and (3) Efforts made by students to facilitate the use of the Natural Sciences kits in the college subject of Natural Sciences Practicum. The data is analyzed by doing content analysis in the form of seeing and determining the same ideas, issues, and concepts (Patton, 1987), or it first arranged into certain codes (Bogdan \& Biklen, 1982). 


\section{FINDING AND DISCUSSION}

In the findings section, the respondents' profile will be discussed including: (1) Distribution of respondents based on sampling locations; (2) The gender of the respondent; (3) Educational background, (4) Teaching class, and (5) Teaching time allotment. Information about the Natural Science kits and the implementation of the Natural Science Practicum, including: (1) Factors supporting the use of the Natural Sciences kits in the college subject of Natural Sciences Practicum; (2) Factors detaining the use of the Natural Sciences kits in the college subject of Natural Sciences Practicum; and (3) Efforts made by students to facilitate the use of the Natural Sciences kits in the college subject of Natural Sciences Practicum.

\section{Respondents' Profile}

\section{Distribution of respondents based on RO location}

Respondents in this study came from five (5) RO's, which are RO of UT Pangkalpinang as many as 30 students (16.95\%); from RO of UT Serang as many as 21 students (11.86\%); from RO of UT Jakarta as many as 47 people (26.55\%); from RO of UT Bandung as many as 40 students (22.60\%); and from RO of UT Denpasar as many as 39 students $(22.03 \%)$. The total number of students becoming research respondents were 177 students (100\%). The distribution of research respondents can be seen in Figure 1.

\section{Figure 1. Distribution of respondents based on regional office}

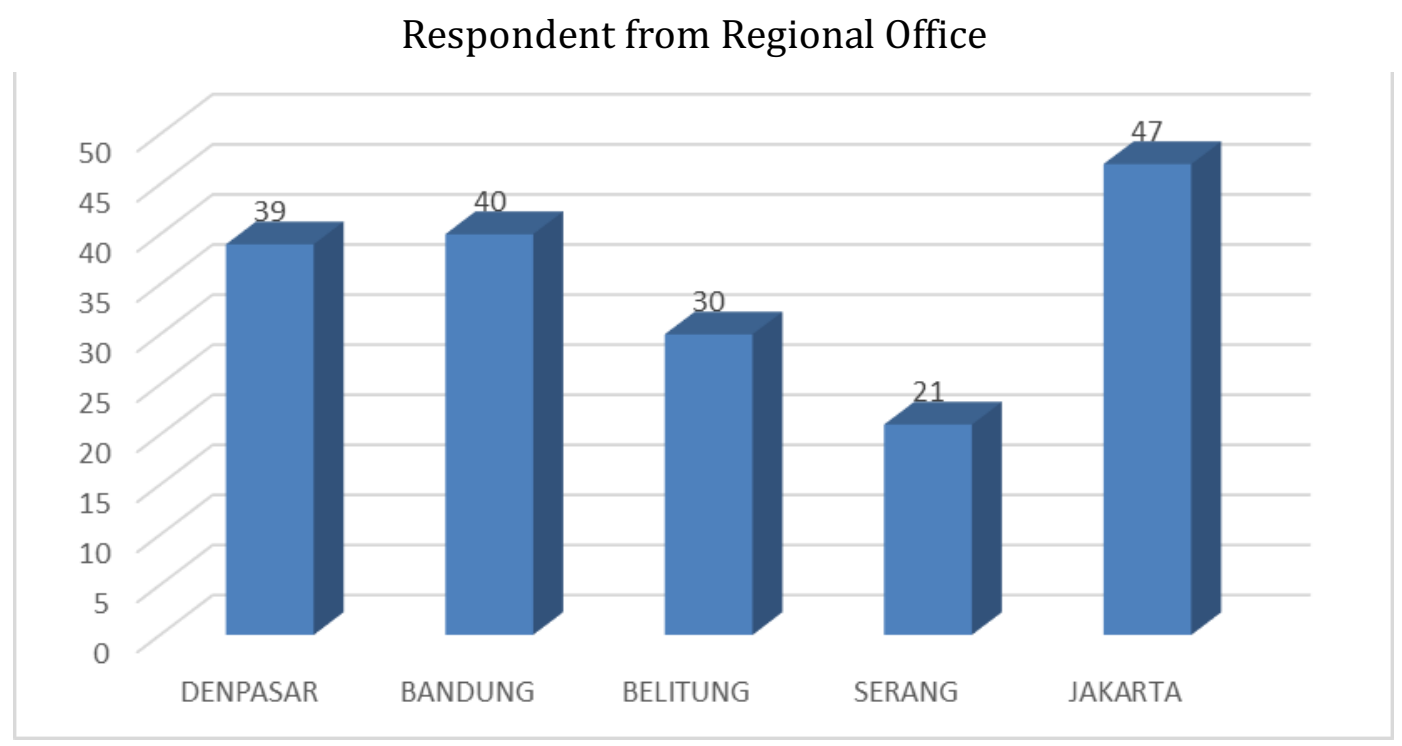

\section{Distribution of respondents based on gender}

The majority of respondents are male showing 136 students (76.84\%), while female respondents are 39 students (22.03\%), the distribution of respondents by gender can be seen in Figure 2. 


\section{Figure 2. Distribution of respondents based on gender}

Respondents' Gender

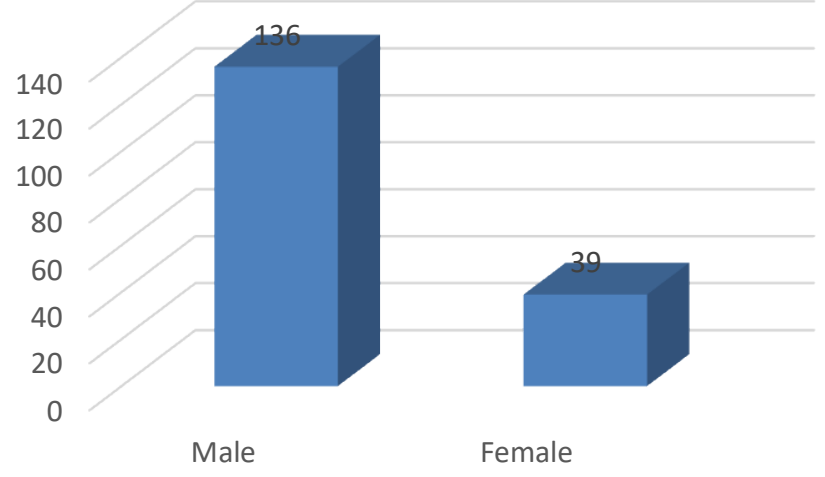

\section{Distribution of respondents based on the educational background}

The majority of the latest education of research respondents are Bachelor/S1 as many as 114 students (64.41\%); diplomas as many as 8 students (4.52\%); Senior High School and equivalent of it as many as 36 students (27.05\%); the remaining 1 person $(0.56 \%)$ has S2 education. The distribution of respondents based on their latest education can be seen in Figure 3.

Figure 3. Distribution of respondents based on the educational background

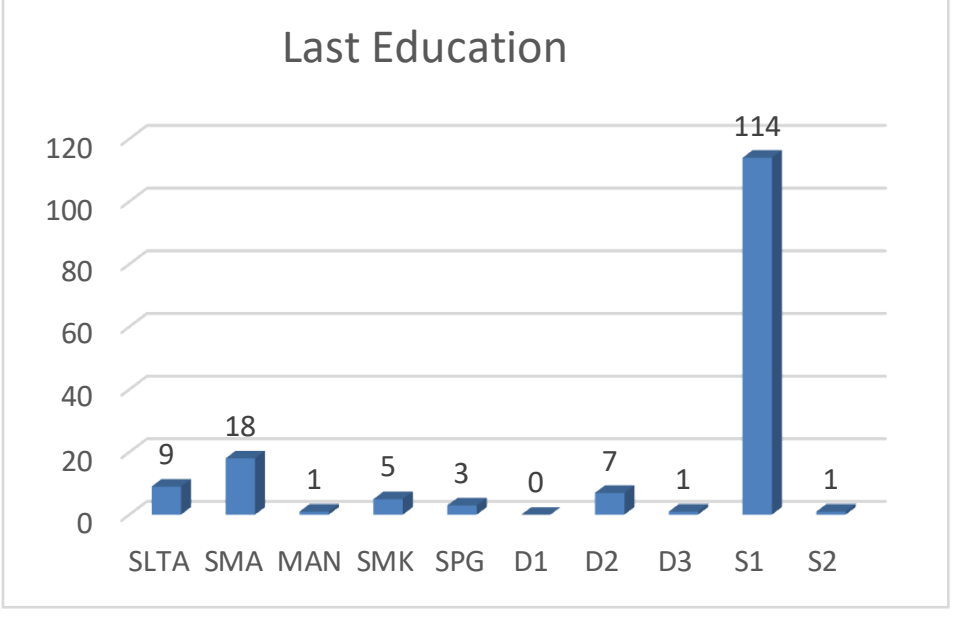

\section{Distribution of respondents based on one teaching in elementary school}

Respondents in this study are elementary school teachers who have taught in elementary schools spread from grade 1 to grade 6 of elementary school, with details of teaching in grade 6 of elementary school as many as 13 people (7.34\%); grade 5 of elementary school as many as 34 people (19.21\%); grade 4 of elementary schools as many as 37 people $(20.90 \%)$; grade 3 of elementary school as many as 29 people (16.38\%); grade 2 of elementary school as many as 33 people (18.64\%); and grade 1 of elementary school as many as 21 people $(11.86 \%)$. The distribution of respondents based on the classroom for teaching in elementary schools can be seen in Figure 4. 
Figure 4. Distribution of respondents based on the classroom for teaching

\section{TEACHING AT GRADE}

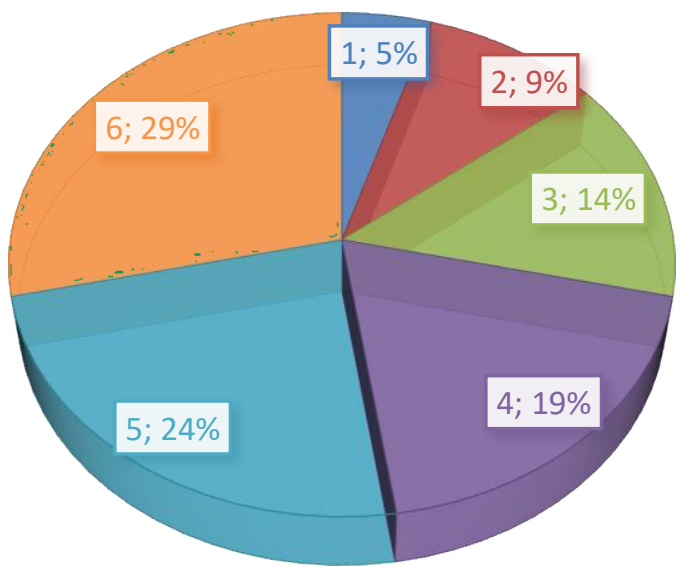

\section{Distribution of respondents based on the length of teaching}

Based on the questionnaire contents in Figure 5, it can be seen that the majority of respondents taught between 1-5 years as many as 72 people (40.68\%); respondents with 6-10 years of teaching are 32 people (18.08\%); respondents with 11-15 years of teaching are 31 people (17.51\%); respondents with $16-20$ years of teaching as many as 9 people $(5.08 \%)$. While the rest, as many as 5 people $(2.8 \%)$, they teach more than 20 years. The distribution of respondents based on their length of teaching in elementary school can be seen in Figure 5.

Figure 5. Distribution of respondents based on the length of teaching

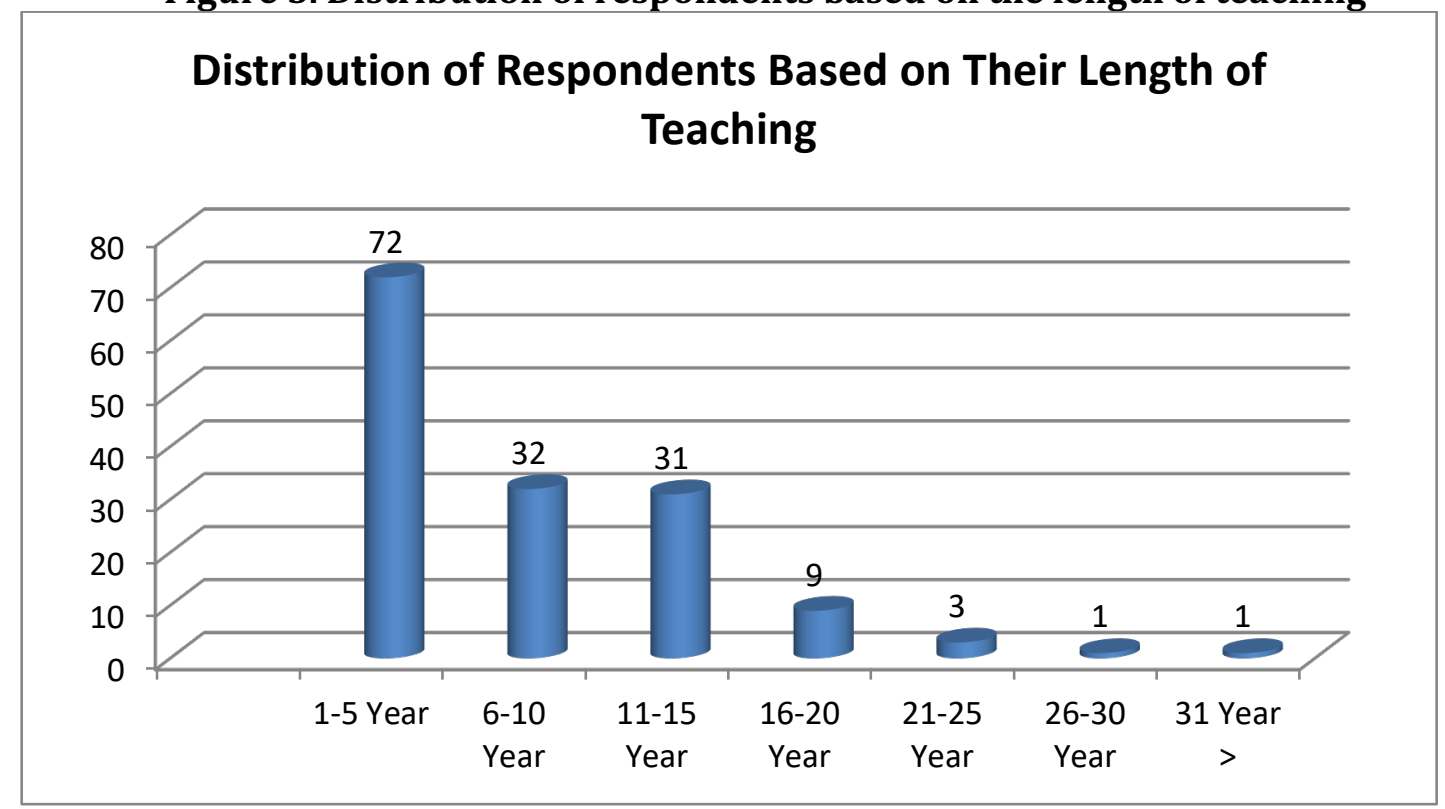

\section{Factors supporting the use of the Natural Science kits in a college subject of Natural Sciences Practicum at the bachelor of ESTE Program - UT}

Meanwhile, there are several factors supporting the use of the Natural Sciences kits in the college subject of Natural Sciences Practicum at bachelor of Elementary School support Education Program, UT, which can be seen in Table 1, including: (1) The Natural Science kits which are in the tutorial room are available in sufficient quantities; (2) The Natural Science kits used to carry out Natural Sciences practicum are in a well maintained condition; (3) There are 
enough guideline for practicum; (4) Practicum guides are easily to be understood by students; (5) Tutors have sufficient ability to guide students in carrying out Natural Sciences practicum; (6) Practicum must be implemented by students and implemented well; and (7) An independent practicum conducted by students can be implemented well by students.

Table 1.

Factors supporting the use of the Natural Science kits in a college subject of Natural Sciences Practicum at bachelor of Elementary School support Education Program, UT

\begin{tabular}{|c|c|c|c|c|c|c|}
\hline \multirow[t]{2}{*}{ No } & \multirow[t]{2}{*}{ Statements } & 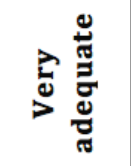 & 莺 & 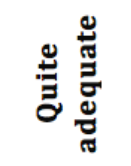 & 莺 & 总 \\
\hline & & (5) & (4) & (3) & (2) & (1) \\
\hline 1 & $\begin{array}{l}\text { Natural Science kits that are in tutorial place are quite } \\
\text { adequate }\end{array}$ & $\begin{array}{c}15 \\
(8,50)\end{array}$ & $\begin{array}{c}81 \\
(45,80)\end{array}$ & $\begin{array}{c}18 \\
(33,30)\end{array}$ & $\begin{array}{c}3 \\
(10.20)\end{array}$ & $\begin{array}{c}1 \\
(1.70)\end{array}$ \\
\hline 2 & $\begin{array}{l}\text { Natural Science kits used to implement the Natural } \\
\text { Science Practicum is in a well-maintained condition }\end{array}$ & $\begin{array}{c}18 \\
(10.20)\end{array}$ & $\begin{array}{c}73 \\
(41.20)\end{array}$ & $\begin{array}{c}63 \\
(35.60)\end{array}$ & $\begin{array}{c}18 \\
(10.20)\end{array}$ & $\begin{array}{l}3 \\
(1.70)\end{array}$ \\
\hline 3 & $\begin{array}{l}\text { Practical guides available in numbers } \\
\text { which is quite adequate }\end{array}$ & $\begin{array}{c}23 \\
(13.00) \\
\end{array}$ & $\begin{array}{c}85 \\
(48.00) \\
\end{array}$ & $\begin{array}{c}61 \\
(34.50) \\
\end{array}$ & $\begin{array}{c}7 \\
(4.00) \\
\end{array}$ & $\begin{array}{c}0 \\
(0.00) \\
\end{array}$ \\
\hline 4 & $\begin{array}{l}\text { Practicum guides are easily to be understood by } \\
\text { students }\end{array}$ & $\begin{array}{c}35 \\
(19.80) \\
\end{array}$ & $\begin{array}{c}94 \\
(53.10) \\
\end{array}$ & $\begin{array}{c}45 \\
(25.40) \\
\end{array}$ & $\begin{array}{c}2 \\
(1.10) \\
\end{array}$ & $\begin{array}{c}0 \\
(0.00) \\
\end{array}$ \\
\hline 5 & $\begin{array}{l}\text { Tutors have sufficient abilities to } \\
\text { guide students in the implementation of the practicum } \\
\text { of Natural Science }\end{array}$ & $\begin{array}{c}75 \\
(42.40)\end{array}$ & $\begin{array}{c}90 \\
(50.80)\end{array}$ & $\begin{array}{c}10 \\
(5.60)\end{array}$ & $\begin{array}{c}0 \\
(0.00)\end{array}$ & $\begin{array}{c}1 \\
(0.60)\end{array}$ \\
\hline 6 & $\begin{array}{l}\text { Practicum that must be implemented by students } \\
\text { and carried out properly }\end{array}$ & $\begin{array}{c}43 \\
(24.30) \\
\end{array}$ & $\begin{array}{c}102 \\
(57.60) \\
\end{array}$ & $\begin{array}{c}30 \\
(16.90) \\
\end{array}$ & $\begin{array}{c}0 \\
(0.00) \\
\end{array}$ & $\begin{array}{c}1 \\
(0.60) \\
\end{array}$ \\
\hline 7 & $\begin{array}{l}\text { An independent practicum by } \\
\text { students can be implemented well by students }\end{array}$ & $\begin{array}{c}37 \\
(20.90)\end{array}$ & $\begin{array}{c}95 \\
(53.70)\end{array}$ & $\begin{array}{c}43 \\
(24.30)\end{array}$ & $\begin{array}{c}0 \\
(0.00)\end{array}$ & $\begin{array}{c}1 \\
(0.60)\end{array}$ \\
\hline
\end{tabular}

\section{Factors detaining the use of the Natural Science kits in a college subject of Natural} Sciences Practicum at the bachelor of ESTE Program - UT

There are several factors detaining the use of the Natural Sciences kits in the college subject of Natural Sciences Practicum at bachelor of Elementary School support Education Program, UT, which can be seen in Table 2, including: (1) Guidelines for the implementation of the Natural Science practicum are difficult to be understood; (2) There are number of natural science material or concepts that must be implemented in practicum courses; (3) There are not enough tools and materials available for practicum; (4) The guidance provided by the tutor is not sufficient enough; (5) Practicum that must be carried out by students is difficult to be carried out; and 6) Practicum which is independent by students is difficult to be carried out. 
Table 2.

Factors detaining the use of the Natural Science kits in a college subject of Natural Sciences Practicum at the bachelor of ESTE Program - UT

\begin{tabular}{|c|l|c|c|c|c|c|}
\hline \multirow{2}{*}{ No } & Statements & & & \\
& & & & & \\
\end{tabular}

The efforts made by students to facilitate the use of the Natural Science kits in a college subject of Natural Sciences Practicum at the bachelor of ESTE Program - UT

There are several effort done by student to facilitate the use of the Natural Sciences kits in the college subject of Natural Sciences Practicum at bachelor of ESTE Program - UT, which can be seen in Table 3, including: (1) Reading and understanding practicum guidelines well; (2) Asking for tutor/instructor guidance if there is practicum material that is difficult to be understood; (3) Looking for tools and practicum replacement materials if there are incomplete practicum materials in the Natural Sciences kits; (4) Under the direction of a tutor/instructor, students prepare incomplete or damaged tools and materials in the Natural Sciences kits; and (5) Working in groups if there are difficulties in carrying out the Natural Science practicum. 
Table 3.

The efforts made by students to facilitate the use of the Natural Science kits in a college subject of Natural Sciences Practicum at the bachelor of ESTE Program - UT

\begin{tabular}{|c|c|c|c|c|c|c|}
\hline No & Statements & 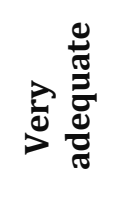 & $\begin{array}{l}\frac{0}{\pi} \\
\frac{\pi}{2} \\
\frac{\pi}{2}\end{array}$ & 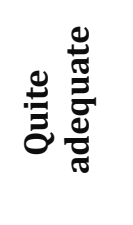 & 冚 & 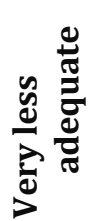 \\
\hline & & (5) & (4) & (3) & (2) & (1) \\
\hline 1 & $\begin{array}{l}\text { Reading and understanding practicum guidelines } \\
\text { well }\end{array}$ & $\begin{array}{c}25 \\
(14.10)\end{array}$ & $\begin{array}{c}116 \\
(65.50)\end{array}$ & $\begin{array}{c}33 \\
(18.60)\end{array}$ & $\begin{array}{c}1 \\
(0.60)\end{array}$ & $\begin{array}{c}0 \\
(0.00)\end{array}$ \\
\hline 2 & $\begin{array}{l}\text { Asking for tutor/instructor guidance if there is } \\
\text { practicum material that is difficult to be } \\
\text { understood }\end{array}$ & $\begin{array}{c}50 \\
(28.20)\end{array}$ & $\begin{array}{c}96 \\
(54.20)\end{array}$ & $\begin{array}{c}28 \\
(15.80)\end{array}$ & $\begin{array}{c}1 \\
(0.60)\end{array}$ & $\begin{array}{c}0 \\
(0.00)\end{array}$ \\
\hline 3 & $\begin{array}{l}\text { Looking for tools and practicum replacement materials } \\
\text { if there are incomplete practicum materials in the } \\
\text { Natural Sciences kits }\end{array}$ & $\begin{array}{c}24 \\
(13.60)\end{array}$ & $\begin{array}{c}92 \\
(52.00)\end{array}$ & $\begin{array}{c}53 \\
(29.90)\end{array}$ & $\begin{array}{c}5 \\
(2.80)\end{array}$ & $\begin{array}{c}0 \\
(0.00)\end{array}$ \\
\hline 4 & $\begin{array}{l}\text { Under the direction of a tutor/instructor, students } \\
\text { prepare incomplete or damaged tools and materials in } \\
\text { the Natural Sciences kits }\end{array}$ & $\begin{array}{c}31 \\
(17.50)\end{array}$ & $\begin{array}{c}90 \\
(50.80)\end{array}$ & $\begin{array}{c}45 \\
(25.40)\end{array}$ & $\begin{array}{c}9 \\
(5.10)\end{array}$ & $\begin{array}{c}0 \\
(0.00)\end{array}$ \\
\hline 5 & $\begin{array}{l}\text { Working in groups if there are difficulties in carrying } \\
\text { out the Natural Science practicum. }\end{array}$ & $\begin{array}{c}54 \\
(30.50)\end{array}$ & $\begin{array}{c}90 \\
(50.80)\end{array}$ & $\begin{array}{c}29 \\
(16.40)\end{array}$ & $\begin{array}{c}2 \\
(1.10)\end{array}$ & $\begin{array}{c}0 \\
(0.00)\end{array}$ \\
\hline
\end{tabular}

The number of experiments in the college subject of Natural Science Practicum that can be carried out using the Natural Science kits at the bachelor of ESTE Program - UT

The number of compulsory trials and the number of optional trials available in the college subject of Natural Science Practicum that can be carried out using the Natural Science kits at bachelor of ESTE Program - UT, which can be seen in Table 4, including: (1) All experiments required in the practicum manual book can be carried out properly; (2) All mandatory experiments (10 trials) can be carried out properly; and (3) All selected trials (4 trials) can be carried out properly.

Table 4.

The number of experiments in the college subject of Natural Science Practicum that can be carried out using the Natural Science kits at the bachelor of ESTE Program - UT

\begin{tabular}{|c|c|c|c|c|c|c|}
\hline NO & Statements & > & 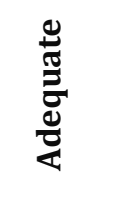 & 芯 & 莺 & 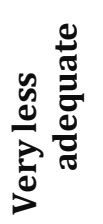 \\
\hline & & (5) & (4) & (3) & (2) & (1) \\
\hline 1 & $\begin{array}{l}\text { All experiments required in the practicum manual } \\
\text { book can be carried out properly }\end{array}$ & $\begin{array}{c}47 \\
(26.60)\end{array}$ & $\begin{array}{c}78 \\
(44.10)\end{array}$ & $\begin{array}{c}48 \\
(27.10)\end{array}$ & $\begin{array}{c}1 \\
(0.60)\end{array}$ & $\begin{array}{c}0 \\
(0.00)\end{array}$ \\
\hline 2 & $\begin{array}{l}\text { All mandatory experiments ( } 10 \text { trials) can be } \\
\text { carried out properly }\end{array}$ & $\begin{array}{c}42 \\
(23.70)\end{array}$ & $\begin{array}{c}88 \\
(49.70)\end{array}$ & $\begin{array}{c}41 \\
(23.20)\end{array}$ & $\begin{array}{c}3 \\
(1.70)\end{array}$ & $\begin{array}{c}0 \\
(0.00)\end{array}$ \\
\hline 3 & $\begin{array}{l}\text { All selected trials ( } 4 \text { trials) can } \\
\text { be carried out properly. }\end{array}$ & $\begin{array}{c}41 \\
(23.20)\end{array}$ & $\begin{array}{c}87 \\
(49.20)\end{array}$ & $\begin{array}{c}46 \\
(26.00)\end{array}$ & $\begin{array}{c}0 \\
(0.00)\end{array}$ & $\begin{array}{c}0 \\
(0.00)\end{array}$ \\
\hline
\end{tabular}




\section{Suitability of Natural Science practicum implementation with the provisions in a college} subject of Natural Sciences Practicum at the bachelor of ESTE Program - UT

Meanwhile, Suitability of Natural Science practicum implementation with the provisions in a college subject of Natural Sciences Practicum at bachelor of ESTE Program - UT, which can be seen in Table 5, including: (1) Natural Science practicum material can be implemented according to the provisions in the practicum manual book; (2) If there are damaged tools and materials in the Natural Science kits, students with the direction of a tutor make a replacement of the damaged tools and materials; and (3) The tutor/instructor gives direction if there are tools and materials available in the Natural Science kits which are incomplete or damaged so that the Natural Science practicum can still be carried out.

Table 5.

Suitability of Natural Science practicum implementation with the provisions in a college subject of Natural Sciences Practicum at the bachelor of ESTE Program - UT

\begin{tabular}{|c|c|c|c|c|c|c|}
\hline NO & Statements & 承 & 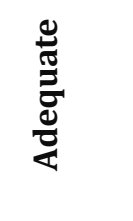 & 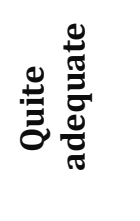 & 离 & 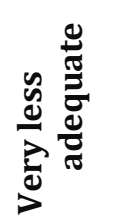 \\
\hline & & (5) & (4) & (3) & (2) & (1) \\
\hline 1 & $\begin{array}{l}\text { Natural Science practicum material can be } \\
\text { implemented according to the provisions in the } \\
\text { practicum manual book }\end{array}$ & $\begin{array}{c}53 \\
(29.90)\end{array}$ & $\begin{array}{c}90 \\
(50.80)\end{array}$ & $\begin{array}{c}31 \\
(17.50)\end{array}$ & $\begin{array}{c}1 \\
(0.60)\end{array}$ & $\begin{array}{c}0 \\
(0.00)\end{array}$ \\
\hline 2 & $\begin{array}{l}\text { If there are damaged tools and materials in the } \\
\text { Natural Science kits, students with the direction } \\
\text { of a tutor make a replacement of } \\
\text { the damaged tools and materials }\end{array}$ & $\begin{array}{c}30 \\
(16.90)\end{array}$ & $\begin{array}{c}74 \\
(41.80)\end{array}$ & $\begin{array}{c}60 \\
(33.90)\end{array}$ & $\begin{array}{c}9 \\
(5.10)\end{array}$ & $\begin{array}{c}1 \\
(0.60)\end{array}$ \\
\hline 3 & $\begin{array}{l}\text { The tutor/instructor gives direction if there are } \\
\text { tools and materials available in the Natural } \\
\text { Science kits which are incomplete or damaged } \\
\text { so that the Natural Science practicum can still } \\
\text { be carried out. }\end{array}$ & $\begin{array}{c}51 \\
(28.80)\end{array}$ & $\begin{array}{c}74 \\
(41.80)\end{array}$ & $\begin{array}{c}43 \\
(24.30)\end{array}$ & $\begin{array}{c}7 \\
(4.00)\end{array}$ & $\begin{array}{c}0 \\
(0.00)\end{array}$ \\
\hline
\end{tabular}

\section{Suitability of scoring of Natural Science practicum report with the provisions in a college} subject of Natural Sciences Practicum at the bachelor of ESTE Program - UT

In the case of scoring of Natural Science practicum report if seen from the provisions in a college subject of Natural Sciences Practicum at the bachelor of ESTE Program - UT, which can be seen in Table 6, including information about: (1) Students can prepare a report on the implementation of Natural Science practicum according to the existing provisions; (2) Practicum reports can be collected by students on time; (3) Tutor guideline and guidance are very useful for students in preparing the Natural Sciences Practicum report; (4) Tutors conduct scoring using the scoring guidelines contained in the Natural Sciences Practicum manual book; and (5) Students are satisfied with the scores they have obtained. 
Table 6.

Suitability of scoring of Natural Science practicum report with the provisions in a college subject of Natural Sciences Practicum at the bachelor of ESTE Program - UT

\begin{tabular}{|c|c|c|c|c|c|c|}
\hline \multirow[t]{2}{*}{ NO } & \multirow[t]{2}{*}{ Statements } & 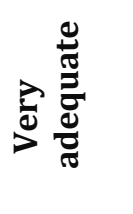 & 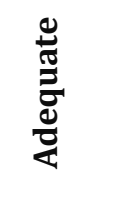 & 总 & 莺 & 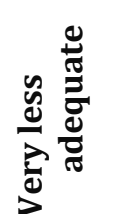 \\
\hline & & (5) & (4) & (3) & (2) & (1) \\
\hline 1 & $\begin{array}{l}\text { Students can prepare a report on the } \\
\text { implementation of Natural Science practicum } \\
\text { according to the existing provisions }\end{array}$ & $\begin{array}{c}41 \\
(23.20)\end{array}$ & $\begin{array}{c}108 \\
(61.00)\end{array}$ & $\begin{array}{c}27 \\
(15.30)\end{array}$ & $\begin{array}{c}0 \\
(0.00)\end{array}$ & $\begin{array}{c}0 \\
(0.00)\end{array}$ \\
\hline 2 & $\begin{array}{l}\text { Practicum reports can be collected by } \\
\text { students on time }\end{array}$ & $\begin{array}{c}56 \\
(31.60)\end{array}$ & $\begin{array}{c}86 \\
(48.60)\end{array}$ & $\begin{array}{c}33 \\
(18.60)\end{array}$ & $\begin{array}{c}1 \\
(0.60)\end{array}$ & $\begin{array}{c}0 \\
(0.00)\end{array}$ \\
\hline 3 & $\begin{array}{l}\text { Tutor guideline and guidance are very useful for } \\
\text { students in preparing the Natural Sciences } \\
\text { Practicum report }\end{array}$ & $\begin{array}{c}78 \\
(44.10)\end{array}$ & $\begin{array}{c}75 \\
(42.40)\end{array}$ & $\begin{array}{c}23 \\
(13.00)\end{array}$ & $\begin{array}{c}0 \\
(0.00)\end{array}$ & $\begin{array}{c}0 \\
(0.00)\end{array}$ \\
\hline 4 & $\begin{array}{l}\text { Tutors conduct scoring using the scoring } \\
\text { guidelines contained in the Natural Sciences } \\
\text { Practicum manual book }\end{array}$ & $\begin{array}{c}51 \\
(28.80)\end{array}$ & $\begin{array}{c}97 \\
(54.80)\end{array}$ & $\begin{array}{c}26 \\
(14.70)\end{array}$ & $\begin{array}{c}1 \\
(0.60)\end{array}$ & $\begin{array}{c}0 \\
(0.00)\end{array}$ \\
\hline 5 & $\begin{array}{l}\text { Students are satisfied with the scores they } \\
\text { have obtained. }\end{array}$ & $\begin{array}{c}57 \\
(32.20)\end{array}$ & $\begin{array}{c}89 \\
(50.30)\end{array}$ & $\begin{array}{c}29 \\
(16.40)\end{array}$ & $\begin{array}{c}0 \\
(0.00)\end{array}$ & $\begin{array}{c}1 \\
(0.60)\end{array}$ \\
\hline
\end{tabular}

\section{DISCUSSION}

Based on the analysis of student responses to the level of difficulty of the Natural Science practicum material, information was obtained showing that most of the students stating that the practicum material was in moderate category as many as 111 respondents (72\%); in easy category as many as 31 respondents (20\%); and in difficult category as many as 13 respondents (8\%); and the rest did not respond. Some respondents said that practicum material was said to be easy for students. It was based on thought that: (1) because every practicum to be carried out is always given clear guidance by the tutor, it will be easy. Besides, the teaching aids or practicum materials to support the implementation of the experiment is easy to be obtained by students; (2) it was said to be easy by students because the tutor explains in detail the steps of the Natural Science practicum before the experiment is carried out as well as there is an explanation from the tutor or instructor when the practicum takes place; (3) it is easy to understand because the practicum handbook is felt to have been completed with an explanation of how the practicum, tools and materials as well as a systematic report are also available in the book and supported by tutors who have mastered the material and mastered how to guide how to conduct experiments properly (Budiastra, et al. 2019).

For students saying that practicum material is said to have a moderate level because practicum material is not too easy or not too difficult, meaning that it can still be done well with the guidance and direction of a tutor or instructor (Subiantoro, 2010). In addition, some respondents said that practicum material was difficult to carry out. The explanation from the respondents as follows: (1) science practicum material is difficult because students feel they do not understand Latin terms or names that are available in Natural Science practicum material, because some of the respondents have never studied material of Natural Science practicum before; (2) some respondents cannot understand the material of Natural Science practicum because they have no background knowledge of natural science or experience in carrying out the Natural Science practicum. 
However, some respondents said that practicum material was said to be easy to be understood because the process of delivering Natural Science practicum material was explained very interestingly, so that even difficult material was easy to be understood by students. Some practicum materials are difficult to be understood because some of the respondents, students who are also elementary school teachers, have never studied Natural Science material or carried out natural Science practicum before (Adji and Rokhiyah, 2011). Some of them have material of Natural Science practicum categorized as being moderate to be understood because even though at first it was difficult to understand, interesting explanations from tutors or instructors made the difficult material to be easy to be understood. The distribution of students based on the level of difficulty in understanding the material of Natural Science practicum can be seen in Figure 6.

\section{Figure 6. Respondents point of view on the Difficulty Level of Natural Science Practicum Materials}

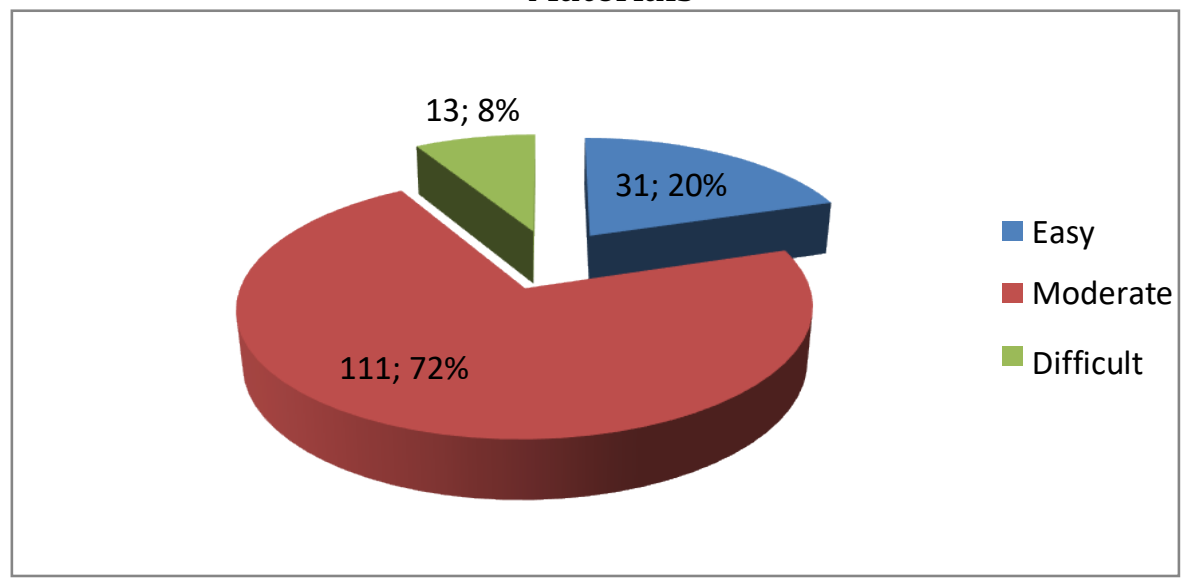

Some weakness or lack of the Natural Sciences Practicum in Elementary Schools in their implementation are: (1) Tutors or instructors who have attended training for being an instructor for the Natural Sciences Practicum at Elementary School Teacher Education Program, UT is difficult to find in several Student Study Group locations; (2) In some remote places, there is a possibility that there are no instructors who have the basic or relevant scientific skills; (3) The equipment in the Natural Sciences kits is incomplete, or in some locations/ places, it is difficult to find a replacement; (4) The available chemicals are often found to be damaged or not functioning properly; (5) The chemicals contained in the Natural Sciences kits, are usually for single use, and they cannot be used for the next practicum activity; and (6) Equipment and materials in the Natural Sciences kits received at the location of the condition are incomplete or not good.

From the results of monitoring of tutorial activities for Natural Sciences practicum, information was obtained that the Natural Sciences kits sent to each study group had not been maximally used for the Natural Sciences practicum activities. Some of the Natural Sciences kits that Student Study Group received were incomplete, for example a report from the Coordinator of Academic Support of RO of UT Mataram (registration period of 2017). In addition, from the report on the results of monitoring the implementation of the face to face tutorial activities of Natural Sciences practicum Program for the Student Study Group in West Jakarta during the registration period of 2017/2018.1, information was obtained that the Natural Sciences kits sent to each Student Study Group was usually only used once and after that the kits was piled up in the tutorial room. There is a tendency for the condition of the Natural Science Kits to be poorly maintained (Budiastra, et al. 2019). To assess the utilization of the Natural Science Kits and the implementation of Natural Sciences Practicum activities in each Student Study Group, 
it is necessary to conduct an evaluation program regarding the use of Natural Science Kits in the college subject of Natural Sciences Practicum at the bachelor of Elementary School Teacher Education Program.

At Student Study Group in Cicalengka, West Java, RO of UT Bandung, tutorial activities were held at SDN 8 Cicalengka, West Java. After using the practicum, the Natural Science kits is kept in one of the rooms in SDN 8 Cicalengka in a well-maintained state. Unlike the case at Student Study Group in Labuan, RO of UT Serang, after being used for practicum activities, the Natural Science kits is given to needed elementary schools after having coordination with the Education Unit in the District of Labuan Pandeglang. From the explanation of the tutor or instructor at Student Study Group in Cicalengka, it is said that the supporting factors for the implementation of the Natural Science practicum: (1) the adequate practicum tools in terms of quantity and quality; (2) practicum manual instructions that are more operational; (3) the tutor or instructor direction/guidance is sufficient to guide students to be able to carry out the practicum, and to guide students in planning/ preparation, implementation, and in reporting; (4) students look enthusiastic when they get more operational and clear instructions.

Obstacles to the implementation of the Natural Science practicum: (1) The availability of number of natural science kits, some of the tools and materials are asked for students to bring from their home, but no one brings the tools and materials needed, and finally the tutor brings them from campus; (2) the measurement tools in the Natural Science kits are lack of precision, such as a spring scale, dynamometer, magnets whose interactions are less clear when compared to other magnets, magnetic powders showing less magnetic field patterns; (3) students are not accustomed to reading the instructions in the college subject of Natural Sciences Practicum in elementary schools. Finally, tutors make practical operational guidelines for students so that students can understand the practical instructions easier; (4) Natural Science kits in elementary schools are rarely used by students because they do not understand how to use tools, how to assemble tools, and in terms of understanding practical work instructions.

\section{A briefing given to tutors is more directed at the tutorial tools and practicum management, but has not touched on the overall utilization of the Natural Science kits either mandatory or optional in the process of Natural Science practicum. \\ (Results of interview with Tutor of the Natural Sciences Practicum, November 11, 2018).}

The positive things from the tutors, they felt they enjoyed being a tutor or instructor of the college subject of Natural Sciences Practicum at the bachelor of ESTE Program - UT. It happens because the enthusiasm for sharing knowledge and guidance during the learning process in a face-to-face tutorial is felt to be very clear and directed.

\section{CONCLUSIONS}

Based on the research results and the discussion, as well as from the results of this study can be concluded as follows: (1) Factors supporting the use of Natural Science Kits in the college subject of Natural Sciences Practicum at the bachelor of ESTE Program - UT, including: (1) the adequate practicum tools in terms of quantity and quality; (2) practicum manual instructions that are more operational; (3) the tutor or instructor direction/guidance is sufficient to guide students to be able to carry out the practicum, and to guide students in planning/ preparation, implementation, and in reporting; (4) students look enthusiastic when they get more operational and clear instructions. 
Some weakness or lack of the Natural Sciences Practicum in Elementary Schools in their implementation are: (1) Instructors who have attended training to become an instructor for the Natural Sciences Practicum at Elementary School Teacher Education Program, UT, is difficult to be found in several Student Study Group locations; (2) In some remote places, there is a possibility that there are no instructors who have the basic or relevant scientific skills; (3) The equipment in the Natural Sciences kits is incomplete, or in some locations/ places, it is difficult to find a replacement; (4) The available chemicals are often found to be damaged or not functioning properly; (5) Equipment and materials in the Natural Sciences kits received at the location of the condition are incomplete or not good; and (6) The chemicals contained in the Natural Sciences kits, are usually for single use, and they cannot be used for the next practicum activity

The efforts made by students and tutor to facilitate the use of the Natural Science kits in a college subject of Natural Sciences Practicum at the bachelor of ESTE Program - UT, including: (1) some of the tools and materials that are not in the Natural Science kits are asked for students to bring it from their home; The tutor makes practical operational instructions more practical so that students can understand the practical instructions easier; (3) in some Student Study Groups, students are invited by instructors to conduct practicum in the place where they teach, for example experiments conducted in high school laboratories, and so on.

Most of the mandatory and optional trials in the Natural Science Practicum course can be carried out using the Natural Science kits of the bachelor of ESTE Program - UT. However, it was found a less precise or thorough tool to support practicum activities. Generally, the activities of scoring of Natural Science practicum report in line with the provisions in a college subject of Natural Sciences Practicum at the bachelor of ESTE Program - UT.

\section{SUGGESTIONS}

From the results of the discussion and conclusions in this study, the following matters can be suggested: (1) Tutors or instructors of practicum require a socialization about the use of Natural Science kits in a practicum; (2) The Natural Sciences kits need to be added so that students can carry out the practicum properly; (3) If possible, a special room is provided to serve as a place for carrying out practicum activities; and (4) Natural Science kits are sent to each Student Study Group, usually only for single use and after that the Natural Science kits are stacked in a room and in poorly maintained conditions. For this reason, it is necessary to make provisions governing the existence of the Natural Science kits after it is used in Student Study Group, so that it can be optimally utilized in teaching and learning activities or for the following tutorial activities.

\section{References}

Adji, S. S., \& Rokhiyah, I. (2011). Kesenjangan antara persepsi dan harapan mahasiswa pada kegiatan tutorial tatap muka mata kuliah praktikum IPA SD [The gap between students' perceptions and expectations in the face-to-face tutorial activities of elementary school science practicum courses]. Jurnal Pendidikan Terbuka Dan Jarak Jauh, 12(2), 100-108.

Belawati, T. (2003). Pengembangan Bahan Ajar [The Development of Teaching Materials]. Jakarta: Universitas Terbuka.

Bogdan, R. C., \& Biklen, S. K. (1982). Qualitative research for education, An introduction to theory and methods. Boston: Allyn and Bacon, Inc.

Budiastra, dkk. (2001). Laporan Semi-Que Pelaksanaan Praktikum FKIP-UT [Semi-Que Report on the Implementation of Practicum FKIP-UT]. Jakarta: Universitas Terbuka.

Budiastra, A. K., Erlina, N., \& Wicaksono, I. (2019). Video-based interaction through teacher working group forum to increase elementary school teachers' professionalism. New Educational Review, 57, 187-199. 
Budiastra, A. K., Erlina, N., \& Wicaksono, I. (2019). The factors affecting teachers' readiness in developing science concept assessment through inquiry-based learning process in elementary schools. Advances in Social Sciences Research Journal, 6(9), 355-366.

Darmayanti, T., Setiani, M. Y., \& Oetojo, B. (2007). E-learning pada pendidikan jarak jauh: konsep yang mengubah metode pembelajaran di perguruan tinggi di Indonesia [E-learning in distance education: concepts that change learning methods in tertiary institutions in Indonesia]. Jurnal Pendidikan Terbuka dan Jarak Jauh, 8(2), 99-113.

Indrawan, I. (2015). Pengantar manajemen sarana dan prasarana sekolah [Introduction to school facilities and infrastructure management]. Deepublish.

Keputusan Menteri Pendidikan Nasional Republik Indonesia Nomor 107/U/2001. Penyelenggaraan program pendidikan tinggi jarak jauh [Implementation of the distance education higher education program]. Jakarta.

McDermott, Lilian C., Shaffer, Peter S., Constantinou, CP. (2000). Preparing teachers to teach physics and physical science by inquiry. Physics Education Journal, 35 (6), 411-416.

Mudjiman, H. (2008). Belajar Mandiri [Self-Motivated Learning]. Cetakan ke 2. Surakarta: LPP dan UNS Press.

Patton, M. C. (1987). How to Use Qualitative Methods in Evaluation. Newbury Park, California: SAGE Publications, Inc.

Prasetyo, Z. K. (2001). Kapita Selekta Pembelajaran Fisika [Capita Selekta Learning Physics]. Jakarta: Pusat Penerbitan Universitas Terbuka.

Rustaman, N. Y. (1995). Peranan praktikum dalam pembelajaran biologi: Bahan pelatihan bagi teknisi dan laboran perguruan tinggi [The role of practicum in learning biology: Training materials for college technicians and laboratory assistance]. Kerjasama FPMIPA IKIP Bandung dengan Direktorat Jenderal Pendidikan Tinggi. Bandung: FPMIPA IKIP.

Subiantoro, A. W. (2010). Pentingnya Praktikum dalam Pembelajaran IPA [The Importance of Practicum in Science Learning]. Yogyakarta: Universitas Negeri Yogyakarta.

Woolnough, Brian E. (1994). Effective Science Teaching. Bristol PA: Open University Press.

Zainuddin, M. (2001). Praktikum [Practicum]. Jakarta: Pusat Antar Universitas Untuk Peningkatan dan

Pengembangan Aktivitas Instruksional Universitas Terbuka. Jakarta: PAU-PPAI-UT. 